\title{
THE PROBLEMS OF PREJUDICIAL PRACTICES IN INDONESIAN COURTS
}

\author{
Jaholden 1, Ediwarman 2, Syafruddin Kalo 3, M Hamdan 4 \\ 1.Doctoral Candidate in Faculty of Law, Universitas Sumatera Utara, \\ 2,3,4. Professor of Law University of North Sumatera, Medan, Indonesia \\ Email: joheldenpolice@gmail.com
}

\begin{abstract}
This research paper sought the problems of prejudicial practices in Indonesian courts. The problems of Indonesian Civil Law System obviously appear after the Reformation which brought the Freedom of Speech with it. If the cases in the New Order Era from 1968 to 1998 never exposed in public discourses, the Reformation Era, in contrast, has provided many channels for justice seekers to show the problems of law system in Indonesia. It concluded that the Indonesian judiciary grants a person the right to take action against forced measures since the arrest, detention, seizure, search of the body or the house, and the examination of letters through the filing of a pre-trial lawsuit. Nonetheless, the Criminal Procedure Code only determines the pretrial enclosure space covering arrest, detention, cessation of investigation and prosecution, compensation, and rehabilitation, while confiscation, search and suspect status are not specified in the Criminal Procedure Code.
\end{abstract}

Keywords: Prejudicial, Habeas Corpus, civil law system, single judge

\section{Introduction}

Pretrial in Indonesia is an adoption sourced from the doctrine of habeas corpus to grant a right to a person whose rights are violated by fighting against the arbitrary act of forced efforts by the investigator through a court judge (Malarangeng, 2012). The court order grants the suspect the right to sue the police or the prosecutor who is detaining him or herself in order to prove the detention is not unlawful or in accordance with applicable law (Adyan, 2014).

The Netherlands and Indonesia are equally based on the civil law system. Pretrial institutions in the Netherlands already know the judge commissioner, while in Indonesia the judge commissioner is unknown. Judge Commissioners in the Netherlands have widespread authority in the pretrial. In addition to the scope of its authority is to assess the validity of the arrest, detention, suspension of investigation, or the cessation of prosecution, as well as to assess whether or not legitimate attempts, foreclosures, or searches are made (Hamzah, 1985). The provisions of pre-trial law in Central Europe also have wide authority. The Law Comission (rechter commissaris) agency is authorized to handle forced, detention, foreclosure, and body and house seizure, including letters checking. Similarly, Judge $d$ 'Instruction in France has extensive powers in preliminary examinations, can check suspects, witnesses, evidence instruments, make news of events, ransacked homes and certain places.

The presence of pretrial institutions in Indonesia is actually based on the doctrine of habeas corpus, but the concept in the Criminal Procedure Code which is valid from 31 December 1981 up to now does not cover pritrial, as it is not as wide and as tight as the original concept of habeas corpus (Eddyono\& Errasmus, 2014). Indonesia Criminal Procedure Code (KUHAP) is not relevant because should be an alternative but not embraced therein. Pretrial practices are often not optimal and minimal use of mechanisms in criminal proceedings.

The authority of Indonesian pretrial judges is very limited, unlike the magistrate or justice of the piece that uses the commissioner's judge. The authority of a pre-trial judge substantively in Article 77 of the Criminal Procedure Code is limited to examine and decide whether or not legal arrest, detention, investigation, termination of prosecution, including compensation or rehabilitation for a person whose case has been terminated, it is no more than that. Although a pretrial judge may declare the legitimacy 
of such acts, this authority is limited after forced efforts. Indonesian pretrial judges tend to be ineffective in supervising investigators or prosecutors in the use of force of forced efforts (Eddyono at all, 2014). Although there is a pre-trial lawsuit, it is all done after all acts of forced effort take place, not at the beginning of an investigation or inquiry. How is it possible to provide citizens protection against possible violations and abuse of authority by investigators if not controlled from the outset.

Thirty-six years of the journey of Law No. 8 of 1981 on the Criminal Procedure Code until now has not been changed is a long enough time to see, understand, and explore the substantive weakness of KUHAP in its implementation. Over a quarter of a century, social, economic and legal changes from technological advances, especially in the field of communication and transportation, have made the world even smaller.

The concept of a commissary judge is not a new idea. Judge Commissioner once applied to Strafvordering $(S v)$ as the procedural law for WetboekvanStraftrecht $(W v S)$. The idea of a commissioner judge was proposed through the draft Criminal Procedure Code of 1974 and reproposed by the National Working Group on the draft KUHAP version 2009. Then the idea of a commissioner's judge in the draft Criminal Procedure Code arose from consideration of the use of unforeseen, pretrial judges only prioritizes the formal aspects of examining the material aspects, and there is an unequal position between apparatus and suspects who are often bullied and violent.

The New Order lasted from 1966 to 1998. The Criminal Procedure Code effective from 31 December 1981 until now has never been revised and promulgated, especially regarding the provisions of the judicial commissioner in the pre-trial. Although it has been proposed in the design of the New Order (1974) and in the order of reform (since 1998 was first proposed in 2002) until now has never been enacted. The extension of authority of the Preliminary Examining Judge (HPP) actually began to develop since the draft of Criminal Procedure Code 2002 version, and especially expensed since the 2004 version of the Criminal Code Bill, which was then consolidated in the 2011 version of the Criminal Procedure Code Bill.

The existence of Preliminary Examining Judge in the 2012 version of the Criminal Procedure Code has a much wider and more complete duty and authority over law enforcement actions in the preadjudication phase than the existing Code. This is an important breakthrough in criminal procedure reform. The commissioner's judge in the draft Criminal Procedure Code has been revised several times. Judge Commissioner in Draft of Code is a court official who is authorized to assess the course of the investigation, prosecution and other authority under this law. The draft Criminal Procedure Code of 2010 adopts a broad scope of pretrial justice including the supervision of a commissioner's judge on the seizure, search, suspect status, arrest, detention, suspension of investigation and prosecution, compensation and rehabilitation, and other authority determined by the Bill such as intercept (interception) involving a commissioner's judge. Until now the Criminal Procedure Code has not yet been enacted so that the judicial act involving the commissioner's judge cannot be applied.

\section{THEORETICAL REVIEWS}

The Indonesian pretrial has not yet had a forum authorized to examine before a forced-action attempt was taken. Abuse of power and arbitrary arrest and detention of a suspect candidate cannot be controlled by an institution such as a judge commissioner in the Netherlands. No court order before investigation and investigation is common. Therefore it is not appropriate if the pretrial judge only examines the formal proof only and disregards the fact.

The role of such a judge is diverged into the purpose of the criminal justice process whose purpose is to seek material truth. It is not an easy matter to discover the material truths if in the pre-adjudication phase, the judge only examines the formal evidence only. Judge Commissioner as a preliminary examination or magistrate judge, almost certainly existed all over the world. The judge of the commissioner can balance the witness, suspect, victim, state, and society so that the balance of interest, but the Indonesian pretrial judge only performs administrative checks. If a person is subjected to forced attempts in the investigation or pre-prosecution phase, the suspect may file a pre-trial lawsuit. A new judge's examination is conducted if there has been a forced attempt. All pretrial 
authorities arise after a forced effort takes place or after a suspect's determination, and the scope is very narrow. The authority of Indonesian pretrial judges is not a moment or act of forced effort. Pretrial judges in the pre-adjudication phase become ineffective in controlling the powers of the large and often mistaken investigators. While the supervision of forced efforts in the concept of magistrate or justice of the piece, not only asked for approval at the beginning of the investigation but also involved community participation.

Justice in Indonesia should apply a commissioner's judge who has the authority of investigating judge and administrative judge, so that this concept can change the mind set against the supervision of the forced effort from a crime control model to a due process model. Judge Commissioner will lead the preliminary examination as a manifestation of the activeness of the judge commissioner. As the role of judges in virtually every Central European country has the authority to actively handle forced, detention, seizure, search and body search and inspection of letters (Adji, 1980). The United States has a magistrate preliminary judge involved in the pre-trial process since the investigation has been conducted or since a person is suspected of a crime. In Dennish system, a suspect to be detained must be brought before the judge every four weeks for review on the order of detention and reviewing the progress of the investigation process (Anggara at all, 2014). Such judge in Italy is called Giudice per le Indagini Preliminary (GIP) to determine the necessary preventative measures such as determining the status of a person or suspect or the defendant should be detained in prison or not, the GIP also overseeing the legitimacy of the act of forced attempts, arrests, , foreclosure, inspection of letters.

A court order as a fundamental right in pre-trial should be obtained before the act of forced effort is made by applying the concept of a commissioner's judge. However, preliminary investigations by justice judges in Indonesia are only conducted if there has been a forced effort. All pretrial judges' authority arises after forced or after-status attempts. If a person has been subjected to forced attempts in the investigation, investigation or pre-adjudication phase then the suspect may file a pre-trial suit.

Attempts to forcibly, seizure, search and suspect status in Indonesia are disputed as pre-trial objects, since Article 77 of the Criminal Procedure Code does not include seizure, search, suspect status setting into pre-trial objects. The seizure mechanisms are set forth in Article 38 to Article 46 of the Criminal Procedure Code, as well as the searching mechanisms have been regulated from Articles 32 to 37 of the Criminal Procedure Code, but confiscation and searches are not included in pre-trial objects in Article 77 of the Criminal Procedure Code.

The object specified in Article 77 of the Criminal Procedure Code only concerns whether or not the arrest, detention, suspension of investigation, or termination of prosecution, damages and or rehabilitation for a person whose criminal cases are terminated at the level of investigation or prosecution.

Foreclosure, for example, an investigator confiscates the goods of a suspect that has nothing to do with a crime without a seizure permit. Is not this supposed to be rationalized? A search is by a policeman against a person's body to search the parts that are not permitted by law. Of course, such violations must be included in the pre-trial object.

\section{Indonesian Current Prejudicial Cases}

Regarding the pre-trial lawsuit for procedural error occasionally when conducting an investigation is not carried out by seizure or searches but a person is immediately assigned his status as a suspect by the investigator. Investigators strongly suspect that he is a suspect based on the minimum requirements of two evidences. Determination of the status of a suspect such as Budi Gunawan case in Decision Number: 04 / Pid.Prap / 2015 / PN.Jkt.Selatan, Date 16 February 2015 included as pre-trial object even though not mentioned in Article 77 in Code.

The sole judge of the South Jakarta District Court adjudicating this case shall declare an Investigation Order (Sprindik) Number: Sprin.Dik 03/01/01/2015 dated January 12, 2015 stipulating the petitioner as a suspect as referred to in Article 12 letter a or b, Article 5 paragraph (2), Article 11 or $12 \mathrm{~B}$ 
UUPTPK juncto Article 55 paragraph (1) of the Criminal Code is illegal and not based on law and therefore investigation Order has no binding power.

A single judge exceeds the limits of the authority of the pretrial institution for entering the examination of the subject matter of the case, namely to examine the objective and subjective elements of the crime, not to examine the validity of the object mentioned in Article 77 of the Criminal Procedure Code. This means that the judge has exceeded the limits of authority given by the pretrial institution in accordance with Article 77 of the Criminal Procedure Code, let alone the judge to examine the evidence as if to reach the final decision is contrary to Article 77 of the Criminal Procedure Code.

The judge also considers the loss of the state or the country's economy. This element is not supposed to be considered in the pre-trial hearing according to Article 77 of the Criminal Procedure Code, because it has already entered the examination of the subject matter of the case. A judge considering the position of the applicant as a law enforcement or state apparatus is appropriate because to determine whether or not a person is designated as a suspect should be able to prove his or her personal identity and position.

However, the consideration of the financial loss of the state or state economy in pre-trial hearing is not appropriate according to Article 77 of the Criminal Procedure Code, because it has entered the subject matter examination and will also be bumped with the principle of nebis in idem which asserts that it shall not prosecute and punish a person twice for a crime or offense same. A person may only be punished once for a crime or offense of the same offense. Attachment of the principle of nebbish in idem in Decision Number: 04 / Pid.Prap / 2015 / PN.Jkt.Selatan as well as lock the case cannot be resubmitted for anyone who is interested in making the sue of Police Corruption cases to the Indonesian Commssion of Corruption Eradication (KPK).

Judge of Boyolali District Court of East Java rejected the pre-trial lawsuit filed by suspect Joko Budi Utomo in 2015 related to a case of mistreatment committed by the suspect to the Congregation of Andong Sucipto during the 2015 election campaign for having exceeded the pre-trial filing limit as stipulated in Article 82 Paragraph (1) letter d in Criminal Procedure Code of Indonesia (http:// koran.tempo.co). The base of the applicant filed a pretrial lawsuit because two of the Boyolali Police Force members who arrested him did not bring an arrest warrant on December 5, 2015, and the arrest warrant was only delivered at $7 \mathrm{pm}$ on December 6, 2015 or more than 24 hours (http:// solorayacyber.com). Article 82 Paragraph (1) Sub-Paragraph d of the Criminal Procedure Code regulates the fall of a pre-trial lawsuit if the principal case has been examined by the court. The case file of the persecution of the three-day Andong Sucipto Sub-district has been declared in the P-21 (complete) to be accelerated in order to abort the pre-trial lawsuit. The speed of the process of delegating cases from Police investigators to the Boyolali District Court seems to pursue pre-trial hearing schedule in order to be declared dead.

\section{Legality of Custodian Case in Medan North Sumatra}

The determination of pretrial objects is also disputed in Decision Number: 04 / Pra.Pid / 2016 / PN.Medan Date February 1, 2016 regarding other acts that were proclaimed by the Petitioner. The basis of the applicant is the exercise of the authority of the investigator and the prosecutor in relation to the search, the seizure in the investigation conducted by the Medan Police Department has not been clear for many years. The pretrial judge granted the pre-trial suit but partly for failing to impose the indemnification to the petitioner and ordering the petitioner to immediately complete the investigation.

Pretrial objects in Decision Number: 70 / Pre.Pid / 2015 / PN.Medan, Date January 14, 2016 is also questioned about the action of the investigator of North Sumatra Police Officer during the arrest of Hendro Kusmartoyo for not signing his arrest warrant and also not included the validity considering the applicant's lawsuit about not signing the arrest warrant.

The case of Hendro Kusmartoyo in Medan has pretrial objects in Decision Number: 09 / Pra.Pid / 2016 / PN.Medan Date February 10, 2016 is also questionable regarding the determination of the 
status of suspects without beginning a proper and reasonable calling process. Police Investigator of Sunggal Office immediately made a forced attempt to arrest the Petitioners. This lawsuit was rejected by a pretrial judge at the Medan District Court on the grounds that the alleged act to the Petitioner included non-infringement so that an arrest could be made immediately. Subsequent Decision Number: 32 / Pre.Pid / 2015 / PN.Medan Date January 25, 2016, questioned the pre-trial object concerning the determination of suspect status without being supported with sufficient evidence or at least two valid evidences. The pre-trial judge granted this pretrial appeal for the whole, but the reason the judge granted only because the act of the applicant was not a crime but was a civil action and issued an Inquiry (SP3) Order to the applicant.

Determination of suspect status without the support of at least two valid evidences is also found in Decision Number 03 / Pre.Pid / 2016 / PN.Gst April 6, 2016. South Nias Police only filed witnesses of investigators and translators but did not submit proof of letter reports on the examination of witnesses, reports of suspects and other evidence pursuant to Article 184 in Code at least two evidences. The judge cannot know and assess to determine his status as a suspect if it does not meet at least two sufficient evidences according to Article 184 in Code.

Subsequently Decision Number: 55 / Pre.Pid / 2015 / PN.Medan Date 16 November 2015 on behalf of Leo Saputra Sianturi filed a pretrial lawsuit to the Medan District Court against the Belawan Sector Police. Belawan police of Medan Municipality arrested the petitioner without an arrest warrant and without an arrest warrant or a warrant for the extension of detention and the letters were never received by the applicant or his family, until a pre-trial suit was filed. The applicant is arrested without a warrant is contradictory to Article 18 paragraph (1) of the Criminal Procedure Code, whereas the alleged act to the applicant is not a hand-picking act, but there are reports from the public. This kind of incident often happens in practice as the previous cases are also identical to this case where the suspect was arrested first then followed Cessation Termination Letter/SP3.

Criminal cases requiring arrest warrants after the suspect is arrested only for hand caught cases. In practice for reports or complaints cases are treated by hand-catching cases. Strangely again the pretrial lawsuit case on behalf of Leo Saputra Sianturi was not granted by a pretrial judge. The facts of the trial proved that the arrest warrant came after the suspect was arrested and never received by the Petitioner or his family, but when a pretrial suit was filed in the Medan District Court suddenly the arrest warrant appeared and was shown by an investigator who had not previously been shown to the applicant or his family. Such matters need to be reinforced in the Criminal Procedure Code; so that investigators will no longer make mistakes in arrest or detention procedures. Substantive pre-trial law provisions have weaknesses concerning the scope of pretrial objects in Article $77 \mathrm{~s} / \mathrm{d}$ Article 83 of the Criminal Procedure Code which is too narrow, which only regulates the validity of arrest, detention, suspension of investigation or cessation of prosecution, as well as compensation and / or rehabilitation for a person whose criminal matters are suspended at the level of investigation and prosecution. Forced attempts, seizures, searches, suspect status assignments are not at all specified in Article 77 to Article 83 of the Criminal Procedure Code, whereas forcible attempts, seizures, searches of bodies and homes are often procrastinated by suspects, including the determination of suspect status.

The provisions of Article 77 of the Criminal Procedure Code do not provide for force, seizure, and searches. Legal experts translate Article 1 point 10 juncto Article 77 of the Criminal Procedure Code contains the meaning of forced effort, although in this article there is no forced effort. Harahap (2006) states that forced efforts are also included in the sense of arrest, detention, search and seizure. The pretrial institution is expected to be a part of the judicial system mechanism that grants the human rights of the suspect under the law to conduct a captive in the course of a forced effort in the process of investigation and / or prosecution, but his practice is far from expectations due to pre-trial law provisions in the formulation of Article 1 number 10 and Article 77 of the Criminal Procedure Code (KUHAP) further leads to a narrow supervision that is only administrative oversight (Luthan at all, 2014).

Interpretation of the formulation of Article 1 point 10 and Article 77 of the Criminal Procedure Code is still not widely held breakthrough. The formulation of Article 1 point 10 and Article 77 of the Criminal 
Procedure Code is still interpreted rigidly and positivistic in which the objects that can be proclaimed are only limited as regulated in Article 1 point 10 and Article 77 of the Criminal Procedure Code, besides that it is still debated, so that the KUHAP nuance is so weak to accommodate the rights wider suspect. Whereas when referring to the philosophy of the intention of the establishment of pretrial institutions is to protect human rights, especially suspects.

Pretrial institutions born of inspiration originating from the right of habeas corpus in the Anglo Saxon judicial system provide fundamental guarantees of human rights. The Habeas Corpus Act grants the right to a person by a court order demanding a detaining official. This is to ensure the protection of deprivation or restriction of independence against the suspect in accordance with applicable laws and human rights guarantees (Kaligis, 2006).

\section{The Weaknesses of Prejudicial System in Indonesia}

Indonesia's subsequent pretrial weaknesses cannot be used to examine the legitimate principle of legitimate force in material terms. The pretrial also cannot be used to test "sufficient initial evidence" as a basis for determining the status of the suspect legally materially. Forced efforts can only be found in doctrine covering the definition of arrest, detention, seizure, search of goods or bodies and the opening of letters with the right of a person suspected of having committed a criminal act (Suriyansyah, 2011). Foreclosures are also included in a rationale (Hidayat, 2010). Assessing the validity of arrest, detention, seizure, cessation of investigation or cessation of prosecution is also the jurisdiction of pre-trial judges, whereas in the Criminal Procedure Code it is not included as a pre-trial object (Yuliarta, 2009).

The scope of pretrial objects should be wider than the pre-trial objective itself to protect the human rights of the suspect against violations of formal and material conditions committed at the level of investigation, investigation and prosecution provided for in articles on arrest, detention, confiscation, mail examination, suspect rights, and on legal aid. The narrowness of the pretrial scope in Article 77 of the Criminal Procedure Code has caused weakness in the implementation of applicative law enforcement policies, among others (Kaligis, 2006):

1. Not all compulsory attempts may be requested for examination to be tested and assessed for their accuracy and accuracy by pre-trial institutions because searches, seizure and opening and inspection of letters are not described in the Criminal Procedure Code.

2. Pretrial is not authorized to examine or appraise an action without the request of the suspect or his or her family or any other party on the suspect's authority, although often the police / prosecutor's actions are arbitrary, but cannot be pre-trialed if not prosecuted by the suspect or his or her family.

3. The attention of judges in pretrial hearings tends to see only formal requirements rather than examine material requirements in the determination of a person subject to arrest or detention.

4. The pretrial ruling is only a determination and request for an explanation from the relevant law enforcement officers, so it is often ignored by law enforcement if the court calls him.

Criminal procedural laws should provide a balance of human rights protection against perpetrators, suspects, victims, and the public. The idea of judicial commissioner formation is based on the use of an un-prejuded forced effort in which seizure and searches are not regulated. The most likely thing is to expand the pretrial authority in Article 77 of the Criminal Procedure Code to cover the existing weaknesses. Limitation of the authority of the pretrial judges is under Article 77 of KUHAP, unlike the magistrate or justice of the piece. Pre-trial institutions in Indonesia are not as well as habeas corpus institutions that are widely known in many literatures. Although pretrial judges may declare the legitimacy of arrest, detention, cessation of investigations or discontinuances of the penitentiary and others, but are limited after forced efforts are made.

The doctrine of experts no longer justifies the pre-trial object narrowly. It is no longer just for the validity of arrest, detention, suspension of investigation or cessation of prosecution, and compensation and / or rehabilitation of a person, whose criminal matters are terminated at the level of investigation or prosecution, but also in the sense of force, seizure, including the examination of letters. Even the scope is developed not only on the formal aspect but also the material aspects. 
The Constitutional Court has issued Decision Number 21 / PUU-XII / 2014 in relation to the scope of pre-trial objects, but does not specify the mechanisms for the performance of the duties and powers of the investigator and the public prosecutor when carrying them out. Moreover, the pre-trial rules in the Criminal Procedure Code only consist of 7 (seven) articles (Article $77 \mathrm{~s} / \mathrm{d}$ Article 83 in Code), do not specify in detail the violations that may be promulgated.

The era of direct democracy demands the formation and renewal of laws governing various spheres of life (national law) (Arif, 2013). One of them is to update the weaknesses of KUHAP. Formally and substantively, legislation should reflect the aspirations of the people (responsive) so that in the process of formation must also involve the active participation of the community itself (Astomo, 2007). The values of Indonesia ideology Pancasila must inspire law reform (Maryanto, 2011), either on the level of substance (legal matter), structure (legal apparatus) or culture (legal culture) (Badriyah, 2010). The principles of democracy and the principles of law should be laid as mutualistic fundament and synergies in the realization of a national legal order (Kelsen, 1961). Indonesia must organize the order of life and social life, nation and state, using the rule of law that democratic.

The comprehensive reform of the Criminal Procedure Code must include substantial, structural and cultural components (Friedman, 2009). There is a close attachment between renewal of substantial components and the cultural component. Substantial components should be built on the cultural component of the nation. Legal reform should include legal substance (substance), legal structure, and legal culture (Marbun, 2014). Renewal of the Criminal Procedure Code that is acceptable to the wider community is sometimes a difficult task. It lies in the fact of controversy between the institution that establishes (executive and legislative) and the people. The establishment of Criminal Procedure Code is as the response and demands of the community along with the increasing complexity of the development of aspects of community life. The difficulty has long felt the Indonesian people since colonized by the Dutch. The difficulty is now more perceived by the Indonesian people as the nation is facing various fundamental social problems in multi-dimensional structural and cultural problems.

Renewal of the Criminal Procedure Code must adapt to the importance of protecting the rights of the people, especially suspects from arbitrary acts. Indonesian Code should not be static and rigid. Pretrial objects shall not be merely about the validity of the detention, seizure, suspension of investigation, or the cessation of prosecutions by the investigator or the public prosecutor.

\section{CONCLUSION}

The Indonesian judiciary grants a person the right to take action against forced measures since the arrest, detention, seizure, search of the body or the house, and the examination of letters through the filing of a pre-trial lawsuit. However, the Criminal Procedure Code only determines the pretrial enclosure space covering arrest, detention, cessation of investigation and prosecution, compensation, and rehabilitation, while confiscation, search and suspect status are not specified in the Criminal Procedure Code. While the concept of commissioner judges in developed countries places one's independence on the highest place to carry out a more effective and fair oversight function.

\section{REFERENCES}

Adji, Oemar Seno, (1980). Law, Criminal Judge, Jakarta: Erlangga.

Adyan, AntoryRoyan, (2014). "Position of Judge Commissioner As Supervisor of Investigator in Conducting Action of Forced Action", Journal of Law Staatsrecht, 1(1).

Anggara, Syahrial, Wiryawan, M. Wagiman, W, WahyudiDjafar, \& Erasmus A.T. Napitupulu, (2014). Academic Paper and Draft Regulation of the Supreme Court of the Republic of Indonesia concerning Procedural Law of Pretrial,Jakarta: Institute For Criminal Juctice Reform (ICJR).

Arif, Yuddin Chandra Nan, (2013). "The Dimension of The Change of Law Viewed From The Erspective of Open Legal System”, Jurnal IUS, 1(1).

Astomo, Putera, (2007). "Establishment of Laws in the Framework of Renewal of National Laws in the Era of Democracy”, JurnalKonstitusi, 11(3).

Badriyah, SitiMalikhatun, (2010).Legal Discovery In The Context of Justice Search, Semarang: BadanPenerbitUniversitasDiponegoro, 
Eddyono, SupriyadiWidodo, WahyudiDjafar, Sufriyadi, Erasmus A. T. Napitupulu, \&Sriyana, (2014).Pretrial in Indonesia: Theory, History, and Practice,Jakarta: Institute For Criminal Juctice Reform (ICJR).

Eddyono, SupriyadiWidodo, \&Napitupulu,Erasmus (2014). Prospect of the Judge of the Preliminary Examiner in the Supervision of Detention in the Draft KUHAP, Jakarta: Institute for Criminal Justice Reform.

Friedman, Lawrence Milton, (2009).The Legal System A Social Perspective, translated by M. Khozin, Legal System of Social Science Perspectives, Bandung: Nusa Media,

Hamzah, Andi, (1985). Introduction to Criminal Procedure Law,Jakarta: Ghalia Indonesia, BalaiAksara, Yudhistira,

Harahap, M. Yahya, (2006). Discussion on the Problems and Implementation of Criminal Procedure Code, Court Judgment, Appeal, Cassation, and Review, Second Edition,Jakarta: SinarGrafika,

Hidayat.Nur, (2010). "Dismissal of Investigation by Police Investigator and its Legal Efforts", JurnalYustitia, 10(1).

Kaligis, Otto Cornelis, (2006). "Corruption as Criminal Acts Should Be Eradicated: Character and Legal Practice in Indonesia”, Jurnal Equality, 11(2): 157-158

Kelsen, Hans, (1961). General Theory of Law and State, New York: Russel\&Russel A Divison of AtheneumPublisher,Inc.,

Luthan, Salman, et al, (2014). Pretrial in Indonesia: Theory, History, and Practice,Jakarta: Institute for Criminal Justice Reform/ICJR,

Malarangeng, AndiBau, (2012). "Pretrial Solution by Judge Based Commissioner RUU KUHAP", JurnalPandecta, 7(1).

Maryanto, (2011). "Urgency of Indonesian Law Reform Based on Pancasila Values", Law Journal, 25(1).

Marbun, rocky, (2014). "Grand Design Politics of Criminal Law and Indonesia's Criminal Law System Based on Pancasila and the Constitution of the Republic of Indonesia 1945", Padjadjaran Journal of Law Science, 1(3),

Suriansyah, (2011). "Some Problems Against Pretrial Existence for Suspect in Criminal Process at Pangkalan Bun District Court of Kotawaringin Barat Regency”, JurnalSocioscientia, 3(2).

Yuliartha, I Gede, (2009).Pretrial Institutions in Current and Future Perspectives in Relation to Human Rights, Semarang Program Magister IlmuHukumUniversitasDiponegoro.

\section{Internet Source:}

http://koran.tempo.co/konten/2016/01/07/390782/Praperadilan-Penganiaya-Camat-di-BoyolaliDitolak, accessed on 18 Oktober 2017.Title "PraperadilanPenganiayaanCamat di BoyolaliDitolak", published at website koran.tempo.co, 7 January 2016.

http://solorayacyber.com/sidang-praperadilan-kasus-penganiayaan-camat-kandas/, accessed on 18 October 2017.ByYulianto, title "SidangPraperadilanKasusPenganiayaanCamatKandas", published at website solorayacyber.com. 